\title{
Bifidobacterium strains inhabiting the gastrointestinal tract of rat as potential probiotics for animals*
}

\author{
E. Wasilewska ${ }^{1}$, L.H. Markiewicz and M. Bielecka \\ Institute of Animal Reproduction and Food Research, Department of Food Microbiology \\ Polish Academy of Sciences \\ Tuwima 10, 10-747 Olsztyn, Poland
}

(Received 8 November 2007; revised version 30 May 2008; accepted 24 June 2008)

\begin{abstract}
The aim of the study was to evaluate in vitro the potential probiotic functionality in the gut of animal-originated bifidobacteria strains. Eleven $B$. animalis and five $B$. pseudolongum strains isolated from Wistar rats were characterized for their tolerance to low $\mathrm{pH}$ and bile, and seven $B$. animalis and four B. pseudolongum strains for their ability to adhere to HT-29 cells and mucus. The strains showed high resistance to three-hour exposure to $\mathrm{pH} 3$ (34-100\% of the population survived) and six-hour exposure to the presence of $3 \%$ bile (28-93\%), as well as differentiated adhesive abilities. The number of bacterial cells attached to 100 HT-29 cells ranged from 9 to 33 and from 17 to 645 for $B$. pseudolongum and $B$. animalis strains, respectively, whereas corresponding levels of adherence per square centimetre of polystyrene-immobilized mucin ranged from $3 \times 10^{5}$ to $4 \times 10^{5}$ and from $5 \times 10^{5}$ to $889 \times 10^{5}$ bacterial cells. Three $B$. animalis strains (KSP4, PS46 and PS11) resistant to low $\mathrm{pH}$ and bile, well-adhering to epithelial cells and mucus were selected as potential probiotics for animals and will be evaluated in future in vivo studies.
\end{abstract}

KEY WORDS: rat, probiotics, gut microflora, acid tolerance, bile resistance, adhesion, Bifidobacterium

\section{INTRODUCTION}

Probiotics are live microorganisms that, when administered through the digestive tract, positively affect the host's health. A variety of microbial species

\footnotetext{
* Supported by the State Committee for Scientific Research, Grant No. 3 P06T 02925

${ }^{1}$ Corresponding author: e-mail: ewbied@pan.olsztyn.pl
} 
have been used as probiotics in human and animal nutrition, among which Lactobacillus and Bifidobacterium strains are most frequently used for humans, whereas Bacillus, Enterococcus, Lactobacillus, Pediococcus, Streptococcus and Saccharomyces yeast are applied as feed additives for livestock (Tannock, 1999; Dunne, 2001; Simon et al., 2001; Griggs and Jacob, 2005; Anadon et al., 2006; Taras et al., 2006). Only a few reports exist concerning the use of bifidobacteria in animal feeding (Mengheri et al., 1991; Abe et al., 1995; Meng et al., 1998; Griggs and Jacob, 2005).

Bifidobacteria are Gram-positive, rod-shaped, anaerobic bacteria that inhabit the gastrointestinal tract of humans and animals, where they constitute a part of the dominant anaerobic flora beneficially affecting host health (Bezkorovainy and Miller-Catchpole, 1989). For years, generally recognized as safe (GRAS), bifidobacteria have been used as active ingredients in functional food products. Studies on the role of bifidobacteria in the maintenance of host health have revealed that probiotic strains not only counteracted proliferation of opportunistic and harmful bacteria and reduced diarrhoea incidence, but also positively influenced digestion, host metabolism and immunity (Tannock, 1999; Dunne, 2001). The use of bifidobacteria in animal feeding could significantly support animal breeding.

Much knowledge about the function of probiotic bifidobacteria is based, however, upon work done in humans, whereas the results might not always be the same in animals. Furthermore, it is generally accepted that probiotic effectiveness is only achieved with a sufficient dose of living cells. Surveys of probiotic products on the market have revealed deficiencies in the viability of probiotic strains, especially in those containing bifidobacteria (Fasoli et al., 2003; Masco et al., 2005). Since probiotic cultures may encounter acidic conditions both in technological processes and during gastric transit, tolerance to low $\mathrm{pH}$ is a critical factor influencing probiotic functionality in the gut. Natural bacterial habitats are settled by different species, thus, it is also of paramount importance that the candidates for probiotics should be selected from the host species, especially if colonization is essential to gain the ultimate goal of application of the probiotic (Fuller, 1992). Therefore, studies on the selection of new strains highly resistant to gastrointestinal and technological conditions able to colonize a host's intestine seem to be of great importance.

Most of the studies on probiotics have focused on the selection of probiotic strains designed for humans. There are only a few reports suggesting that animaloriginated bifidobacteria such as B. animalis and B. pseudolongum strains may play a role in intestinal mucosal defence (Bezkorovainy and Miller-Catchpole, 1989; Mengheri et al., 1991; Meng et al., 1998). Likewise, to the best of our knowledge, there is no previous publication encompassing a larger number of animal-originated strains in terms of their sensitivity to gastrointestinal conditions 
or adhesive abilities. Some authors have described the resistance to unfavourable gastric conditions of $B$. animalis subsp. lactis strains, closely related to $B$. animalis subsp. animalis species inhabiting animal intestines (Masco et al., 2004, 2005, 2007). Our previous investigations revealed that the rat's colon harbours bifidobacteria from the species of B. animalis and B. pseudolongum, with the first being predominant (Wasilewska et al., 2003).

The aim of the present study was to characterize strains of $B$. animalis and B. pseudolongum for their sensitivity to an acidic environment and presence of bile as well as their ability to adhere to HT-29 epithelial-like cells and mucin. Although these assays are not fully sufficient to predict the functionality of strains in the gut, they are considered as the most important prerequisites in the selection of Bifidobacterium strains to be used as probiotics.

\section{MATERIAL AND METHODS}

\section{Bacterial strains and culture conditions}

All bifidobacteria strains tested (see Table 1) were isolated in our laboratory from Wistar rats and identified to species using phenotypic and molecular methods (Wasilewska et al., 2003).

Strains were maintained frozen at $-70^{\circ} \mathrm{C}$ in reconstituted skim milk $(5 \%$ dry wt.) supplemented with sucrose $(10 \%)$ at a ratio of $1: 2$. Before every experiment, strains from frozen stocks were subcultured twice in Garche's broth (Teraguchi et al., 1982), containing in grams per litre: bacto peptone 20.0, yeast extract 2.0, L-cysteine hydrochloride 0.4 , lactose $10.0, \mathrm{CH}_{3} \mathrm{COONa} 6.0, \mathrm{MgSO}_{4} \times 7 \mathrm{H}_{2} \mathrm{O} 0.12$, $\mathrm{Na}_{2} \mathrm{HPO}_{4} \times 12 \mathrm{H}_{2} \mathrm{O} 2.5, \mathrm{KH}_{2} \mathrm{PO}_{4} 2.0$, and agar 1.0; $\mathrm{pH}$ after sterilization and cooling, 6.4. The broth was inoculated with $10^{6}-10^{7}$ bifidobacterial cells ( $3 \%$ inoculum) and incubated in anaerobic jars (Gas Pak anaerobic system $\mathrm{H}_{2}+\mathrm{CO}_{2}$, Oxoid, UK) at $37^{\circ} \mathrm{C}$ until the stationary phase was achieved $(\mathrm{pH} \sim 4.4)$.

\section{Tolerance to low $\mathrm{pH}$}

Active cultures were thoroughly mixed and transferred quantitatively into two test tubes, in the first, the $\mathrm{pH}$ was adjusted to 3.0 with sterile $1 \mathrm{~N} \mathrm{HCl}$, whereas into the second (control) an equivalent volume of sterile distilled water was added. Both tubes were incubated in a tissue culture incubator (Cytoperm 8088, Hereus Instruments $\mathrm{GmbH}$, Austria) in an atmosphere with lowered oxygen content $\left(5 \% \mathrm{O}_{2}\right.$ and $22 \% \mathrm{CO}_{2}$ ) at $37^{\circ} \mathrm{C}$ for $3 \mathrm{~h}$. Numbers of live bacterial cells were counted as colony forming units (CFU) per $\mathrm{ml}$ on Garche's agar. The cultures were neutralized 
with $1 \mathrm{~N} \mathrm{NaOH}$ before plating. The plates were incubated anaerobically (Gas Pak anaerobic system) at $37^{\circ} \mathrm{C}$ for $48 \mathrm{~h}$. Survival was calculated as the percentage of surviving population relative to the control population.

\section{Resistance to bile salts}

The procedure was similar as described above, however, the $\mathrm{pH}$ of the cultures was adjusted to 6 with $1 \mathrm{~N} \mathrm{NaOH}$ before transferring into tubes and then a $15 \%$ solution of ox bile (Sigma) was added to a final concentration of $3 \%$. The exposure to bile lasted for $6 \mathrm{~h}$.

\section{Adhesion to HT-29 cells}

Seven B. animalis and four B. pseudolongum strains listed in Table 3 were tested for their adhesion to epithelial cells. Epithelium-like HT-29 cell line was purchased from Deutsche Sammlung von Mikroorganismen und Zellkulturen (DSMZ). HT29 cells were grown routinely in Dulbecco's modified Eagle's minimal essential medium (DMEM) (Gibco BRL) supplemented with $2 \mathrm{mmol} / 1$ of L-glutamine, 1\% $(\mathrm{v} / \mathrm{v})$ of non-essential amino acids and $10 \%(\mathrm{v} / \mathrm{v})$ of inactivated $\left(30 \mathrm{~min}, 56^{\circ} \mathrm{C}\right)$ foetal calf serum (Gibco BRL). For all experiments, cells were cultured in a tissue culture incubator (Cytoperm 8088, Hereus Instruments $\mathrm{GmbH}$, Austria) at $37^{\circ} \mathrm{C}$ in a $5 \% \mathrm{CO}_{2}-95 \%$ air atmosphere and $80 \%$ humidity.

For the bacterial adhesion assay, HT-29 cells were inoculated at a concentration of $2 \times 10^{4}$ cells per $\mathrm{cm}^{2}$ of glass coverslips placed in six-well tissue-culture plates (Nunc, Germany). The culture medium was changed every other day and well differentiated monolayers were used at a post-confluence phase after 18-20 days of incubation.

Overnight bifidobacterial cultures ( $24 \mathrm{~h}$-old) were harvested by centrifugation at $5000 \mathrm{~g}$ for $10 \mathrm{~min}$, washed in sterile phosphate buffer saline (PBS, pH 7.2) and resuspended in a mixture of modified Garche's broth (specially prepared according to a tissue culture procedure) and Dulbecco's MEM medium (at a ratio of 1:1) to a final concentration of $1 \times 10^{9} \mathrm{CFU}$ per $\mathrm{ml}\left(\mathrm{OD}_{550}=1.2\right)$. The bacterial suspensions were added to the monolayers washed twice with PBS buffer in the amount of about $1 \times 10^{8}$ bacterial cells per $\mathrm{cm}^{2}$ of a well, and incubated for $1 \mathrm{~h}$ under conditions described for HT-29 cells. After incubation, the monolayers were washed five times with sterile PBS to remove non-adherent bacteria, preserved in graded methanol series: $25,50,75$ and $96 \%(\mathrm{v} / \mathrm{v})$ by immersing for $5 \mathrm{~min}$ in each solution, next Gram stained and analysed microscopically. Adherence was evaluated in 20 random microscopic fields and the number of bacterial cells attached per 100 epithelial cells was calculated. Each experiment was conducted in duplicate. 


\section{Binding to mucus}

The strains tested towards adhesion to mucus are listed in Table 3. Adhesion to mucus was determined according to the method described by Cohen and Laux (1995) with some modification. In brief, $1 \mathrm{mg} / \mathrm{ml}$ of porcine mucin (Sigma; M2378) was diluted in HEPES ( $N$-2-hydroxy-ethyl-piperazine-N'-2-ethanesulfonic acid)Hank's buffer (HH; 10 mM HEPES; pH 7.4) and immobilized with $250 \mu 1$ on polystyrene microtitre 24-well plates (Nunc) by overnight incubation at $4^{\circ} \mathrm{C}$.

Freshly multiplied bacterial strains were harvested by centrifugation $(5000 \mathrm{~g}$ for $10 \mathrm{~min}$ ), washed twice with $\mathrm{HH}$ buffer and resuspended in $\mathrm{HH}$. The optical density of bacterial suspensions at $600 \mathrm{~nm}$ was adjusted to $0.5 \pm 0.02$ in order to standardize the number of bacteria $\left(1 \times 10^{8}-2.5 \times 10^{8} \mathrm{CFU}\right.$ per $\left.\mathrm{ml}\right)$.

The wells with immobilized mucus were washed twice with $500 \mu \mathrm{HH}$ to remove excess mucus. Afterwards, a suspension of $250 \mu 1$ of each strain was added to two parallel wells. After $1 \mathrm{~h}$ incubation at $37^{\circ} \mathrm{C}$, the wells were washed twice with $500 \mu \mathrm{HH}$ to remove unattached cells and thereafter the number of bacterial cells attached to mucus was determined. To this end, $1 \mathrm{ml}$ of Triton X-100 (1\% solution in HH buffer) was added to each well, next the wells were left for $5 \mathrm{~min}$ at room temperature and thoroughly scrapped with a sterile pipette tip in order to release all the attached bacterial cells to the suspension. Since it was impossible to scoop out the whole suspension inside the well, and also in order to correct for intra-assay variation, $0.5 \mathrm{ml}$ of the bacterial suspension from two parallel wells were mixed together and analysed as a one trial. The number of bifidobacteria attached per well was counted as CFU using the pour plate method. Incubation of the plates was carried out at $37^{\circ} \mathrm{C}$ for $48 \mathrm{~h}$ under anaerobic conditions. Each adhesion assay was performed in duplicate. The final results were expressed as the number of bacterial cells attached per $\mathrm{cm}^{2}$ of the surface covered with mucin.

\section{Scanning electron microscopy}

Monolayers of the epithelial cells on glass coverslips with the attached bacterial cells were used for scanning electron microscopic (SEM) studies. After the adhesion assay the monolayers were fixed with $2.5 \%$ glutaraldehyde for $1 \mathrm{~h}$ at room temperature, washed twice in PBS and postfixed in $2 \% \mathrm{OsO}_{4}$ for $30 \mathrm{~min}$. Afterwards, the samples were washed three times in PBS and dehydrated in a graded acetone series: 25, 50, 75, 90 and three times in 100\% (v/v) by immersing for $5 \mathrm{~min}$ in each solution, and then dried at the critical point using liquid $\mathrm{CO}_{2}$ as the transition medium. Dehydrated samples were coated with gold in a vacuum evaporator (JOEL, JEE-4X) and examined with a JEOL 1200EX TEMSCAN electron microscope equipped with an EM-ASID10 scanning device, at $80 \mathrm{kV}$. 


\section{Statistical analysis}

All results are presented as the average of at least two independent experiments with standard deviation. Each experiment was performed with two parallels to correct for an intra-assay variation. A simple correlation coefficient was calculated to measure the correlation between the features tested.

\section{RESULTS}

Eleven B. animalis and five B.pseudolongum strains isolated from rat faeces were tested for their sensitivity to low $\mathrm{pH}$ or the presence of bile. The results showing the behaviour of the strains in the presence of stress factors are reported in Tables 1 and 2. After 3-h exposure to $\mathrm{pH} \mathrm{3,} \mathrm{the} \mathrm{survival} \mathrm{of} \mathrm{all} \mathrm{the}$ Bifidobacterium strains ranged from 34 to $102 \%$ of the population (Table 1). A comparison of inhibitory effects of bile salts on the strains yielded similar results. After 6-h exposure to the presence of 3\% of ox bile in the medium, the number of live cells decreased about 1.1 to 3.6-times, which means $28-93 \%$ survivability of bacterial cells (Table 2). No significant correlation was found between the two tested features $(\mathrm{r}=-0.17)$.

Table 1. Viability of the tested Bifidobacterium strains after exposure to low $\mathrm{pH}^{1}$

\begin{tabular}{|c|c|c|c|c|}
\hline \multirow[t]{2}{*}{ Strain } & \multirow[t]{2}{*}{ Origin $^{2}$} & \multicolumn{2}{|c|}{$\begin{array}{l}\text { Number of Bifidobacterium cells, } \\
\qquad \text { CFU } / \mathrm{ml}, \times 10^{7}\end{array}$} & \multirow{2}{*}{$\begin{array}{c}\text { Survival }^{3} \\
\%\end{array}$} \\
\hline & & in control & after exposure to low $\mathrm{pH}$ & \\
\hline B. animalis PS11 & A/duodenum & $69.2 \pm 6.8^{4}$ & $70.8 \pm 4.6$ & 102 \\
\hline B. animalis PS37 & $\mathrm{A} /$ caecum & $44.7 \pm 7.3$ & $45.7 \pm 0.1$ & 102 \\
\hline B. animalis PS46 & $\mathrm{A} /$ caecum & $55.0 \pm 3.6$ & $56.3 \pm 3.7$ & 102 \\
\hline B. animalis KSP4 & $\mathrm{B} /$ faeces & $55.7 \pm 4.5$ & $26.6 \pm 4.5$ & 48 \\
\hline B. animalis KSP5 & $\mathrm{B} /$ faeces & $61.7 \pm 1.0$ & $61.7 \pm 0.4$ & 100 \\
\hline B. animalis KSP6 & $\mathrm{B} /$ faeces & $35.5 \pm 2.1$ & $25.1 \pm 1.3$ & 71 \\
\hline B. animalis KS7 & $\mathrm{C}$ faeces & $41.7 \pm 2.7$ & $33.1 \pm 2.2$ & 79 \\
\hline B. animalis $\mathrm{KS} 1 \mathrm{~b} 2$ & $\mathrm{D} /$ faeces & $20.4 \pm 3.4$ & $6.9 \pm 0.7$ & 34 \\
\hline B. animalis $\mathrm{KS} 7 \mathrm{~d} 3$ & $\mathrm{D} /$ faeces & $40.7 \pm 2.4$ & $31.6 \pm 0.6$ & 78 \\
\hline B. animalis KS20a1 & $\mathrm{D} /$ faeces & $38.9 \pm 2.5$ & $20.4 \pm 1.9$ & 52 \\
\hline B. animalis $\mathrm{KS} 29 \mathrm{a} 3$ & $\mathrm{D} /$ faeces & $63.2 \pm 4.1$ & $63.2 \pm 4.1$ & 100 \\
\hline B. pseudolongum PS14 & $\mathrm{A} /$ colon & $76.0 \pm 7.4$ & $26.5 \pm 4.3$ & 35 \\
\hline B. pseudolongum PS34 & $\mathrm{A} /$ caecum & $28.8 \pm 1.1$ & $30.9 \pm 1.6$ & 107 \\
\hline B. pseudolongum PS36 & $\mathrm{A} /$ caecum & $48.1 \pm 6.2$ & $28.0 \pm 1.1$ & 58 \\
\hline B. pseudolongum PS85 & $\mathrm{A} /$ jejunum & $38.5 \pm 1.9$ & $39.4 \pm 1.9$ & 102 \\
\hline B. pseudolongum KSI-9 & E/faeces & $133.6 \pm 10.9$ & $47.0 \pm 6.1$ & 35 \\
\hline
\end{tabular}

${ }^{1}$ the strains were exposed to $\mathrm{pH} 3$ for $3 \mathrm{~h} ;{ }^{2}$ the capital letter denotes the source rat; ${ }^{3}$ survival is shown as percentage of surviving population relative to population in control tube; ${ }^{4}$ mean \pm standard deviation 
Table 2. Viability of the tested Bifidobacterium strains after exposure to bile salts ${ }^{1}$

\begin{tabular}{|c|c|c|c|}
\hline \multirow{2}{*}{ Strain } & \multicolumn{2}{|c|}{ Number of Bifidobacterium cells, CFU/ml, $\times 10^{7}$} & \multirow{2}{*}{$\begin{array}{c}\text { Survival }^{2} \\
\%\end{array}$} \\
\hline & in control & after exposure to bile salts & \\
\hline B. animalis PS11 & $43.3 \pm 4.9^{3}$ & $34.0 \pm 3.3$ & 79 \\
\hline B. animalis PS37 & $26.0 \pm 5.9$ & $16.0 \pm 5.6$ & 62 \\
\hline B. animalis PS46 & $17.5 \pm 3.4$ & $14.7 \pm 3.8$ & 84 \\
\hline B. animalis KSP4 & $45.4 \pm 6.6$ & $37.2 \pm 3.6$ & 82 \\
\hline B. animalis KSP5 & $38.9 \pm 1.3$ & $25.1 \pm 3.0$ & 65 \\
\hline B. animalis KSP6 & $66.1 \pm 2.3$ & $50.1 \pm 3.0$ & 76 \\
\hline B. animalis KS7 & $63.2 \pm 4.1$ & $47.0 \pm 6.1$ & 74 \\
\hline B. animalis $\mathrm{KS} 1 \mathrm{~b} 2$ & $17.8 \pm 4.0$ & $16.6 \pm 2.0$ & 93 \\
\hline B. animalis $\mathrm{KS} 7 \mathrm{~d} 3$ & $23.4 \pm 3.7$ & $15.8 \pm 2.6$ & 68 \\
\hline B. animalis KS20a1 & $38.1 \pm 3.7$ & $26.3 \pm 0.9$ & 69 \\
\hline B. animalis $\mathrm{KS} 29 \mathrm{a} 3$ & $23.9 \pm 6.9$ & $8.6 \pm 1.4$ & 36 \\
\hline B. pseudolongum PS14 & $21.7 \pm 8.3$ & $12.4 \pm 1.6$ & 57 \\
\hline B. pseudolongum PS34 & $24.0 \pm 5.7$ & $15.8 \pm 2.6$ & 66 \\
\hline B. pseudolongum PS36 & $19.5 \pm 1.3$ & $14.0 \pm 1.6$ & 72 \\
\hline B. pseudolongum PS85 & $13.9 \pm 5.5$ & $3.9 \pm 2.7$ & 28 \\
\hline B. pseudolongum KSI-9 & $76.0 \pm 7.4$ & $35.6 \pm 4.6$ & 47 \\
\hline
\end{tabular}

${ }^{1}$ the strains were exposed to $3 \%$ ox bile for $6 \mathrm{~h} ;{ }^{2}$ survival is shown as percentage of surviving population relative to population in control tube; ${ }^{3}$ mean \pm standard deviation

Epithelial-like HT-29 cells were used to assess the ability of the Bifidobacterium strains to adhere to epithelial cells. The adherence of the tested strains was differentiated and the number of bacterial cells attached to 100 HT-29 cells amounted from 9 to 645 (Table 3).

Table 3. Adhesion of the Bifidobacterium strains to HT29 cells and to mucus

\begin{tabular}{|c|c|c|}
\hline \multirow{3}{*}{ Strain } & \multicolumn{2}{|l|}{ Adhesion } \\
\hline & to HT29 cells & to immobilized mucin \\
\hline & bacterial cell number/100 HT29 cells ${ }^{1}$ & CFU number $/ \mathrm{cm}^{2}, \times 10^{5}$ \\
\hline B. animalis PS11 & $155 \pm 21$ & $495 \pm 300$ \\
\hline B. animalis $\mathrm{PS} 37$ & $17 \pm 3$ & $664 \pm 134$ \\
\hline B. animalis PS46 & $645 \pm 41$ & $360 \pm 60$ \\
\hline B. animalis KSP4 & $150 \pm 19$ & $889 \pm 209$ \\
\hline B. animalis $\mathrm{KS} 7$ & $39 \pm 10$ & $5 \pm 1$ \\
\hline B. animalis $\mathrm{KS} 20 \mathrm{a} 1$ & $67 \pm 24$ & $5 \pm 1$ \\
\hline B. animalis $\mathrm{KS} 29 \mathrm{a} 3$ & $45 \pm 12$ & $21 \pm 8$ \\
\hline B. pseudolongum PS14 & $13 \pm 5$ & $3 \pm 0$ \\
\hline B. pseudolongum PS36 & $17 \pm 8$ & $3 \pm 1$ \\
\hline B. pseudolongum PS 85 & $33 \pm 9$ & $4 \pm 1$ \\
\hline B. pseudolongum KSI-9 & $9 \pm 3$ & $3 \pm 1$ \\
\hline
\end{tabular}

${ }^{1}$ the number of bacterial cells attached to 100 epithelial HT29 cells in monolayer; mean \pm standard deviation; ${ }^{2}$ the number of bacterial cells attached to $1 \mathrm{~cm}^{2}$ of the surface covered with mucin 
The highest number of attached cells was observed for B. animalis PS46. Two other B. animalis strains, PS11 and KSP4, also adhered well ( $\sim 150$ cells), whereas the four remaining $B$. animalis strains and all B. pseudolongum strains tested adhered weakly (9-67 cells). Bacterial cells adhered to the monolayers of epithelial-like HT-29 cells in a diffuse way - as dispersed single cells, or in a cluster (Figures 1 and 2).
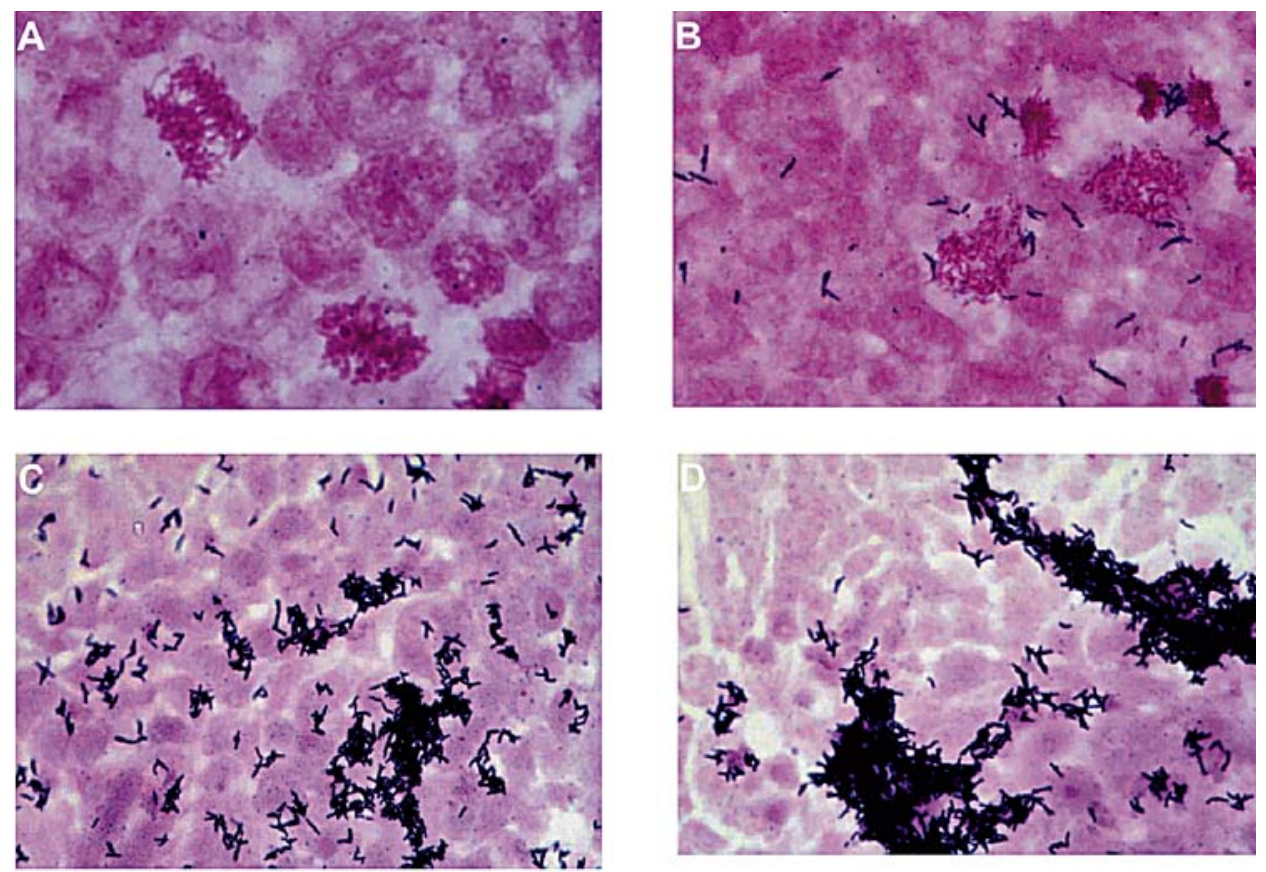

Figure 1. Light micrographs of B. pseudolongum PS14 showing no adherence (A, magnification $\times 1000)$ and $B$. animalis strain PS37 showing diffuse adherence $(B, \times 1000)$ and strain PS46 adhering diffusively and in clusters $(\mathrm{C}, \mathrm{D}, \times 750)$ to HT29 cells. Methanol fixed, Gram stained
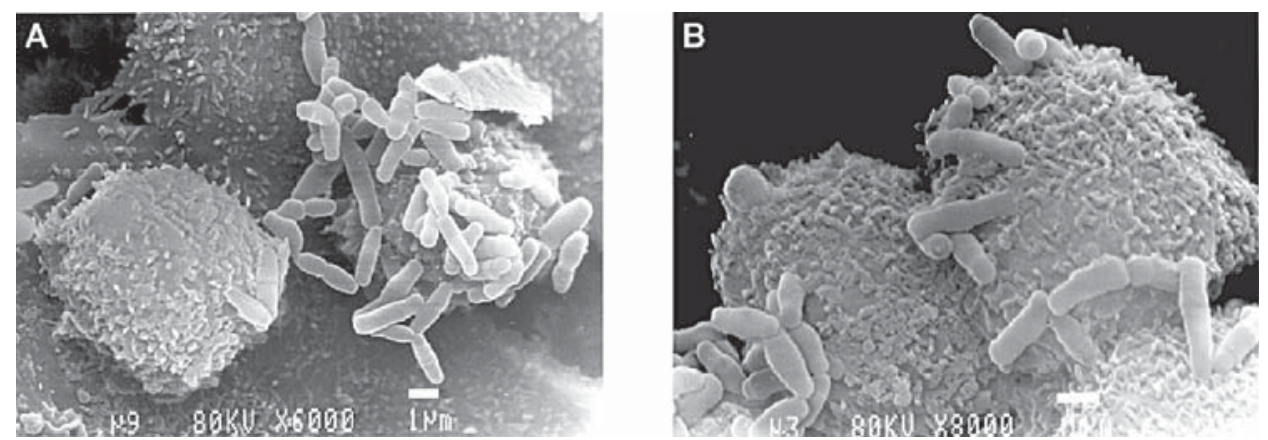

Figure 2. Scanning electron micrographs of B. animalis PS46 showing adherence in clusters (A) and diffuse adherence onto the brush border of HT29 cells (B) 
The tested bifidobacterial strains were also able to bind to mucus, and their adherence to mucin was as much differentiated as their adhesion to epithelial cells (Table 3). The highest binding rates were observed for B. animalis PS11, PS37, PS46 and KSP4 strains $\left(360-889 \times 10^{5}\right.$ bacterial cells attached per $\mathrm{cm}^{2}$ of the surface covered with mucin). The other strains, except for well-adhering B. animalis KS29a3 $\left(21 \times 10^{5}\right.$ cells) showed weak binding abilities to mucin, below $5.5 \times 10^{5}$ cells per $\mathrm{cm}^{2}$ (Table 3 ). An insignificant positive linear correlation $(\mathrm{r}=0.32)$ was observed between adhesion of the tested strains to epithelial cells and to mucin. In general, the strains adhering well to epithelial cells also adhered well to mucin. However, B. animalis PS37 cells adhered weakly to HT-29 cells and strongly to mucin.

\section{DISCUSSION}

Resistance to gastric acidity and bile salts as well as attachment to mucus or epithelial cells are the most important prerequisites for the effectiveness of probiotics in the host gut (Charteris et al., 1998). So far, most of the studies on probiotics have been focused on the selection of probiotic strains designed for humans and originating from humans, therefore animal-originated bifidobacteria have been studied very rarely. Resistance to unfavourable gastric conditions is a rare property among human-originated bifidobacterial species, such as B. bifidum, $B$. infantis, B. longum, B. breve, B. adolescentis or B. catenulatum, a great majority of the strains belonging to those species appeared to be sensitive to low $\mathrm{pH}$ or bile (Clark and Martin, 1994; Lankaputhra and Shah, 1995; Zavaglia et al., 1998). The performed studies revealed that the tested animal-originated strains survived the 3-h exposure to $\mathrm{pH} 3$ well. In all cases, 0 to merely 2.8 -fold reduction of live cells was observed, whereas survival at the level of $>10^{6} \mathrm{CFU} / \mathrm{ml}$ is sufficient for probiotic effectiveness in the gut (Charteris et al., 1998; Collado and Sanz, 2006). Resistance to low $\mathrm{pH}$ and bile of single animal-originated strains of B. animalis and B. pseudolongum (originating from type or industrial collections) was observed by Lankaputhra and Shah (1995) and Zavaglia et al. (1998). Among the other tested bifidobacteria, strains of B. animalis subsp. lactis seem to show the highest tolerance to physiological and technological stress conditions and, as a consequence, have been preferentially included in probiotic products in the food industry, although many researchers stress the importance of host specificity of probiotic strains (Jayamanne and Adams, 2006; Masco et al., 2007). The B. lactis strains were isolated from fermented milk and, as they are closely related to $B$. animalis species, are classified at a subspecies level of $B$. animalis (Meile et al., 1997; Masco et al., 2004). The observed resistance of $B$. animalis strains isolated 
from rats may be a species-specific feature; however, more studies encompassing a greater number of $B$. animalis strains originating from different animal species should be performed. Due to high tolerance to low $\mathrm{pH}, B$. animalis strains can also be more suitable for technological processing than other bifidobacteria. Our previous research on the survival of $B$. animalis strains in commercial bioyoghurts with $\mathrm{pH}$ 4.5-4.7 during 4 weeks of storage under refrigeration revealed merely a 2-4-fold reduction of live bifidobacterial cells (Bielecka et al., 2000).

Resistance to stress factors of the tested animal-originated strains was confirmed during their exposition to bile. The applied $3 \%$ concentration of bile corresponds to the top physiological concentrations of bile in the human gut and makes up an equivalent of $1.5 \%$ of bile salts. Likewise, in an acidic environment, all tested B. animalis and B. pseudolongum strains survived the 6-h exposure to bile well, although in comparison with their survivability at $\mathrm{pH} 3$, the numbers of viable cells of the strains tested were slightly reduced. Nevertheless, the applied high concentration of bile and the observed survival rate suggest that the tested strains may be good candidates for the elaboration of probiotic products.

Interaction of probiotic bacteria with the intestinal mucosa may enhance the possibility for colonization, immune system modulation, and defence against enteropathogens (Tannock, 1999; Dunne, 2001). Unlike sensitivity to unfavourable gastrointestinal conditions, the tested strains differed in their adhesion to both mucosal enterocytes and mucus. The experiments revealed a dissimilarity of the adhesive properties of both tested Bifidobacterium species, and also a strong diversity of the adhesive abilities among the $B$. animalis strains. All well-adhering strains belonged to $B$. animalis species and four out of the eleven strains tested strongly adhered to mucus, whereas only one strain showed strong adherence to epithelial cells. Crociani et al. (1995) described good adhesion of two B. animals and one B. pseudolongum strain to Caco-2 cells. Good adherence of some $B$. animalis subsp. lactis strains to mucus has also been documented in other recent papers (Kirjavainen et al., 1998; He et al., 2001; Rinkinen et al., 2003). However, all those strains originated from type or industrial culture collections.

An important function of beneficial microflora is to form a barrier against colonization of the gastrointestinal tract by pathogenic bacteria. Commensal bacteria colonizing the mucus layer adjacent to the epithelium block receptors and protect the intestine from pathogen invasion. Light and scanning electron microscopy studies of the adhesion to HT-29 cells showed that the tested bifidobacterial cells adhered in clusters, probably to mucus secreted by goblet cells, or in diffuse wayto a brush border of enterocytes (Figures 1 and 2). This suggests that the receptors for bacterial adhesion on mucus may be different, or present in different numbers than on enterocytes, but also that some bifidobacterial cells can be able to form biofilm on the mucosal layer and nearby goblet cells. Such a hypothesis is in 
agreement with high adhesion of some strains to mucus, especially those isolated directly from the intestine. Our previous scanning electron microscopy studies of bacterial adhesion to rat colon revealed that bifidobacteria adhered to intestinal epithelium by filaments, also connecting bacterial cells and consequently forming characteristic microcolonies (Bielecka et al., 1998). Bernet et al. (1993) observed higher adhesion of some human-originated bifidobacterial strains to HT29-MTX (a homogenous subpopulation of goblet cells) than to Caco-2 cells. The ability of probiotic bacteria to attach to host mucus seems to be of a great importance as it ensures mutual interaction. Enterocytes are continuously exfoliated from the tips of the villi and replaced with new cells migrating out of the crypt to reach the villous apex. The strains adhering to both mucus and enterocytes seem to be well predisposed to intestinal colonization. Our previous in vitro research revealed that the $B$. animalis PS46 strain, well adhering to HT-29 cells and mucin, also strongly adhered to the intestinal wall of rat colon (Bielecka et al., 1998).

In conclusion, among the tested strains three B. animalis strains (PS11, PS46 and KSP4) adhered well to mucin and enterocytes and can be considered to be potential probiotic candidates. Although the ecology of animal-type bifidobacteria has been studied very rarely, it is known that both B. animalis and B. pseudolongum strains are natural inhabitants of a majority of animals (hogs, chickens, turkeys, cattle, calves, piglets, sheep, mice, rats, dogs) (Bezkorovainy and Miller-Catchpole, 1989). All of them can be potential probiotic recipients; nevertheless, in vivo studies on the evaluation of the effectiveness of selected strains in host gut are necessary.

\section{REFERENCES}

Abe F., Ishibashi N., Shimamura S., 1995. Effect of administration of bifidobacteria and lactic acid bacteria to newborn calves and piglets. J. Dairy Sci. 78, 2838-2846

Anadon A., Martinez-Larranaga M.R., Martinez M.A., 2006. Probiotics for animal nutrition in the European Union. Regulation and safety assessment. Regul. Toxicol. Pharmacol. 45, 91-95

Bernet M.F., Brassart D., Neeser J.R., Servin A.L., 1993. Adhesion of human bifidobacterial strains to cultured human intestinal epithelial cells and inhibition of enteropathogen-cell interactions. Appl. Environ. Microbiol. 59, 4121-4128

Bezkorovainy A., Miller-Catchpole R. (Editors), 1989. Biochemistry and Physiology of Bifidobacteria. CRC Press Inc. Boca Raton, Florida

Bielecka M., Biedrzycka E., Frejnagiel S., 1998. Scanning and light microscopy to study the adhesion of the Bifidobacterium. Pol. J. Food Nutr. Sci. 7/48, S3, 108-115

Bielecka M., Majkowska A., Biedrzycka E., Biedrzycka El., 2000. Microbiological changes in modified yoghurts during manufacture and storage. Food Biotechnol. 17, 283-289

Charteris W.P., Kelly P.M., Morelli L., Collins J.K., 1998. Ingredient selection criteria for probiotic microorganisms in functional dairy foods. Int. J. Dairy Technol. 51, 123-136

Clark P.A., Martin J.H., 1994. Selection of bifidobacteria for use as dietary adjuncts in cultured dairy foods: III - Tolerance to simulated bile concentrations of human small intestines. Cult. Dairy Prod. J. 29, 18-21 
Cohen P.S., Laux D.C., 1995. Bacterial adhesion to and penetration of intestinal mucus in vitro. Methods Enzymol. 253, 309-314

Collado M.C., Sanz Y., 2006. Method for direct selection of potentially probiotic Bifidobacterium strains from human feces based on their acid-adaptation ability. J. Microbiol. Meth. 66, 560563

Crociani J., Grill J.P., Huppert M., Ballongue J., 1995. Adhesion of different bifidobacteria strains to human enterocyte-like Caco-2 cells and comparison with in vivo study. Lett. Appl. Microbiol. $21,146-148$

Dunne C., 2001. Adaptation of bacteria to the intestinal niche: probiotics and gut disorders. Inflamm. Bowel Dis. 7, 136-154

Fasoli S., Marzotto M., Rizzotti L., Rossi F., Dellaglio F., Torriani S., 2003. Bacterial composition of commercial probiotic products as evaluated by PCR-GDDE analysis. Int. J. Food Microbiol. $82,59-70$

Fuller R. (Editor), 1992. Probiotics. The Scientific Basis. Chapman and Hall (UK)

Griggs J.P., Jacob J.P., 2005. Alternatives to antibiotics for organic poultry productions. J. Appl. Poultry Res. 14, 750-756

He F., Ouwehand A.C., Hashimoto H., Isolauri E., Yoshimi B., Salminen S., 2001. Adhesion of Bifidobacterium spp. to human intestinal mucus. Microbiol. Immunol. 45, 259-262

Jayamanne V.S., Adams M.R., 2006. Determination of survival, identity and stress resistance of probiotic bifidobacteria in bio-yoghurts. Lett. Appl. Microbiol. 42, 189-194

Kirjavainen P.V., Ouwehand A.C., Isolauri E., Salminen S.J., 1998. The ability of probiotic bacteria to bind to human intestinal mucus. FEMS Microbiol. Lett. 167, 15-189

Lankaputhra W.E.V., Shah N.P., 1995. Survival of Lactobacillus acidophilus and Bifidobacterium spp. in the presence of acid and bile salts. Cult. Dairy Prod. J. 30, 2-7

Masco L., Crockaert C., Van Hoorde K., Swings J., Huys G., 2007. In vitro assessment of the gastrointestinal transit tolerance of taxonomic reference strains from human origin and probiotic product isolates of Bifidobacterium. J. Dairy Sci. 90, 3572-3578

Masco L., Huys G., De Brandt E., Temmerman R., Swings J., 2005. Culture-dependent and cultureindependent qualitative analysis of probiotic products claimed to contain bifidobacteria. Int. J. Food Microbiol. 105, 221-230

Masco L., Ventura M., Zink R., Huys G., Swings J., 2004. Polyphasic taxonomic analysis of Bifidobacterium animalis and Bifidobacterium lactis reveals relatedness at the subspecies level: reclassification of Bifidobacterium animalis as Bifidobacterium animalis subsp. animalis subsp. nov. and Bifidobacterium lactis as Bifidobacterium animalis subsp. lactis subsp. nov. Int. J. Syst. Evol. Microbiol. 54, 1137-1143

Meile L., Ludwig W., Rueger U., Gut C., Kaufmann P., Dasen G., Wenger S., Teuber M., 1997. Bifidobacterium lactis sp. nov., a moderately oxygen tolerant species isolated from fermented milk. Syst. Appl. Microbiol. 20, 57-64

Meng Q., Kerley M.S., Russel T.J., Alle G.L., 1998. Lectin-like activity of Escherichia coli K88, Salmonella choleraesuis, and Bifidobacterium pseudolongum of porcine gastrointestinal origin. J. Anim. Sci. 76, 551-556

Mengheri E., Nobili F., Vignolini F., Pesenti M., Brandi G., Biavati B., 1991. Bifidobacterium animalis protects intestine from damage induced by zinc deficiency in rats. J. Nutr. 129, 22512257

Rinkinen M., Westermarck E., Salminen S., Ouwehand A.C., 2003. Absence of host specificity for in vitro adhesion of probiotic lactic acid bacteria to intestinal mucus. Vet. Microbiol. 97, 55-61

Simon O., Jadamus A., Vahjen W., 2001. Probiotic feed additives-effectiveness and expected modes of action. J. Anim. Feed Sci. 10, 51-67 
Tannock G.W. (Editor), 1999. Probiotics a Critical Review. Horizon Scientific Press, Wymondham (UK)

Taras D., Vahjen W., Macha M., Simon O., 2006. Performance, diarrhea incidence, and occurrence of Escherichia coli virulence genes during long-term administration of a probiotic Enterococcus faecium strain to sows and piglets. J. Anim. Sci. 84, 608-617

Teraguchi S., Kawashima T., Kuboyama M., 1982. Selective cell counting of bifidobacteria in commercial dairy and pharmaceutical products. In: Proceedings of XXI Dairy Congress. Moscow $1(2), 2,375$

Wasilewska E., Bielecka M., Markiewicz L., 2003. Numerical analysis of biochemical and morphological features of bifidobacteria as a tool for species characteristics and identification. Pol. J. Food Nutr. Sci. 12/53 S2, 149-156

Zavaglia G.A., Kociubiński G., Perez P., De Antoni G., 1998. Isolation and characterisation of Bifidobacterium strains for probiotic formulation. J. Food Protect. 61, 865-873 